\title{
Imagined futures: fictional expectations in the economy
}

\author{
Jens Beckert
}

\section{MPIfG Journal Article}

Jens Beckert: Imagined Futures: Fictional Expectations in the Economy. In: Theory and Society 42(3), 219-240 (2013). Springer The original publication is available at the publisher's web site: https://doi.org/10.1007/s11186-013-9191-2

The MPIfG Journal Articles series features articles by MPIfG researchers and visiting scholars published in peer-reviewed journals. Max Planck Institute for the Study of Societies (MPIfG) Cologne | www.mpifg.de

\begin{abstract}
Starting from the assumption that decision situations in economic contexts are characterized by fundamental uncertainty, this article argues that the decision-making of intentionally rational actors is anchored in fictions. "Fictionality" in economic action is the inhabitation in the mind of an imagined future state of the world and the beliefs in causal mechanisms leading to this future state. Actors are motivated in their actions by the imagined future and organize their activities based on these mental representations. Since these representations are not confined to empirical reality, fictional expectations are also a source of creativity in the economy. Fictionality opens up a way to an understanding of the microfoundations of the dynamics of the economy. The article develops the notion of fictional expectations. It discusses the role of fictional expectations for the dynamics of the economy and addresses the question of how fictional expectations motivate action. The last part relates the notion of fiction to calculation and social macrostructures, especially institutions and cultural frames. The conclusion hints at the research program developing from the concept of fictional expectations.
\end{abstract}

Keywords Expectations · Uncertainty · Economy · Promises · Trust · Innovation · Creativity $\cdot$ Motivation $\cdot$ Economic sociology $\cdot$ Future $\cdot$ Rationality $\cdot$ Microfoundations

On what basis do actors make decisions in economic contexts? According to economic theory, decisions are based on rational calculations of the outcomes associated with the various possible choices. According to sociological approaches to the economy, decisions are anchored in social structures, especially institutions, networks, and cultural frames.

In this article, I want to contribute a different perspective on the question of the microfoundations of economic action, giving weight to a much underemphasized aspect of it. Starting from the assumption that decision situations in economic contexts are characterized by fundamental uncertainty, I argue that the decision-

J. Beckert $(\bowtie)$

Max Planck Institute for the Study of Societies, Paulstr. 3, 50676 Köln, Germany

e-mail: Beckert@mpifg.de 
making of intentionally rational actors is anchored in fictions. By intentional rationality I refer to actors who want to enhance their utility but do not necessarily know what strategy will lead them to achieve this end. ${ }^{1}$ By "fictions" I refer to images of some future state of the world or course of events that are cognitively accessible in the present through mental representation. "Fictionality" in economic action is the inhabitation in the mind of an imagined future state of the world. Actors are motivated in their actions by the imagined future state and organize their activities based on these mental representations. The mental representations of future states I call "fictional expectations". Fictional expectations in the economy take narrative form as stories, theories, and discourses. Since these representations are not confined to empirical reality, fictionality is also a source of creativity in the economy. Including fictionality in a theory of decision-making opens up a way to an understanding of the microfoundations of the economy's dynamics and growth. Recognition of the human capability of imagining possible future states of the world provides a basis for anchoring a theory of the capitalist economy in a theory of action; it is also a crucial basis for an understanding of the value of goods and of how cooperation dilemmas are overcome (Beckert 2013). Fictional expectations are not limited to the economy but are relevant in all spheres of human action. ${ }^{2}$ This article, however, focuses on the economy.

I first provide a brief overview of economic and sociological approaches to explaining economic decision-making. This will sharpen the point of departure advanced in the article. Second, I develop the notion of fictional expectations to be applied here and the role of stories through which fictions obtain a narrative structure. In the third part, I discuss the role of fictional expectations in innovation and thereby for the dynamics of the economy. Following this, I address how fictional expectations motivate action. In the last section, I relate the notion of fiction to the role of calculation and social macrostructures in economic decision-making. Finally, in the conclusion I hint at the relevance of fictional expectations for the macrodevelopment of the economy and indicate questions for the research program developing from the concept of fictional expectations.

\section{From rational to fictional expectations}

To understand the role played by imaginaries of the future it is necessary to pay attention to the time dimension in decision-making and the role of uncertainty. Action takes place in the present but is directed towards the future (Mische 2009). Making a choice means to evaluate possible courses of action in light of a future desired state. While research in the social sciences typically explains

\footnotetext{
${ }^{1}$ This is not to deny the crucial role of routine behavior also in economic contexts (Camic 1986; Tappenbeck 1999, p. 48). The discussion here, however, refers only to a type of action in which actors are reflexive in the sense that they make decisions based on a deliberate consideration of alternatives, weighted against each other with regard to the desirability of their expected outcomes.

2 Though fictional expectations do exist in all spheres of social life, I would hypothesize that they are more volatile in economic contexts of capitalist societies, because behavior in this sphere is less normatively regulated. This contingency of expectations is a foundation for the innovativeness of capitalist economies but is also a cause of its restlessness and susceptibility to crises stemming from rapid fluxes in expectations.
} 
present action from past occurrences (Mahony 2000), I argue here that it is the future that shapes the present-or, to be more specific: it is the images of the future that shape present decisions.

Due to uncertainty stemming from the openness of the future, decisions cannot be explained as the outcome of calculation of optimal choices (Beckert 2002; Orléan 2011). In situations characterized by certainty or risk (Knight [1921] 1985) actors can identify all possible future states and know probabilities regarding the likelihood of their occurrence. Assuming a fixed set of preferences, given factor endowments and restrictions, standard economic theory assumes that actors calculate the choice that maximizes their expected utility. To do so, actors systematically scrutinize all possible alternative combinations and calculate the consequences of all options. This makes it possible to arrange the various options in a rank order of utility and to construct complete indifference maps across all feasible trade-offs. The macroeconomic result is an equilibrium that can be deduced mathematically based on the starting conditions and the assumptions made in the theory. The future enters into this model in the form of rational expectations (Lucas 1972; Muth 1961). Assuming market pressures and the systematic use of all available information, rational expectations theory states that the predictions actors make with regard to economically relevant variables in the future are correct, in the aggregate, because all individual errors are random. Hence, the predicted outcomes do not differ systematically from the resulting market equilibrium. As a consequence, the uncertainty entailed in the future is transformed into a state predictable by forecast, allowing for the rational calculation of optimal choices.

The assumption that decisions in economic contexts can be optimal choices based on rational expectations has been criticized within economics. The critiques doubt the assumptions that actors can gain a full understanding of their environment (Keynes 1936/1964, p. 152), that they have the cognitive capabilities to process the available information (Güth and Kliemt 2010; Simon 1957), and they emphasize the role of cognitive biases (Allais 1953; Camerer et al. 2003) as well as the unknowability of the future due to novelty (Buchanan and Vanberg [1984] 2008, p. 380f). The complexity of decision situations, unforeseeable interaction effects, and genuine novelty through unpredictable innovations and the choices of other actors make it impossible to predict the future as already implied in the present. It is this "fundamental uncertainty" (Dequech 2006) characterizing important decisions in economic contexts that renders the model of calculation ineffective. Rather than leading to optimal outcomes, in situations characterized by fundamental uncertainty "choices represent a gamble in an unanalyzable world" (Augier and Kreiner 2000: 677). ${ }^{3}$

Despite this unpredictability of the future, actors in the economy must form expectations, among other things, with regard to technological development, consumer preferences, prices, availability of raw materials, the strategies of competitors, the demand for labor, the trustworthiness of promises, the state of

\footnotetext{
${ }^{3}$ In part, this is a problem of lack of thoroughness of economic analysis (Hellwig 1998, p. $719 \mathrm{ff}$.). However, the problem cannot be reduced to superficiality of analysis. In practical terms, actors are simply overburdened and therefore cannot take all relevant information into account (Elster 2009). And with regard to novelty, the necessary information for optimizing decisions is simply not available at the time of decision making (Dequech 2003).
} 
the natural environment, political regulations, and the interdependencies among these factors. On what basis are these expectations formed if they are not rational calculations of what will indeed be the case? What are expectations under conditions of uncertainty?

Sociological approaches to this question have emphasized the role of social macrostructures for shaping actors' expectations. Action, according to Parsons, does not consist of "ad hoc "responses" (Parsons 1951, p. 5) but is based on expectations of the reactions of alter ego. These expectations are seen as being determined by the meaning structures (culture) of the social system. More generally, approaches in economic sociology see action as being anchored in networks, institutions, and cultural scripts that direct choices (Callon 1998, p. 11ff.; Granovetter 1985; Dobbin 2004). ${ }^{4}$ This is not to say that there would not have been advances in economic sociology that allow for a more prominent role of agency (Barbalet 2010; Beckert 2003; Storper and Salais 1997). These approaches usually make the uncertainty and indeterminacy of decision situations the starting point of their reasoning and bring to the fore the need for actors to interpret the social situation. ${ }^{5}$

But what informs these interpretations of the situation? I suggest in this article that expectations under conditions of uncertainty can be productively analyzed by the use of the concept of "fictions". By the term "fiction" I refer to present imaginaries of future situations that provide orientation in decision-making despite the uncertainty inherent in the situation. By not being bound to rational calculation, fictions do not have to be true but must be convincing. They are therefore open to the influence of collective beliefs and manipulations by powerful actors. They can even "crowd out" rational expectations in situations characterized by certainty or risk. While fictions help in "overlooking" uncertainty in decision-making by providing seemingly good reasons for specific decisions, they are at the same time also a source of the uncertainty they are responding to, because the plethora of possible imaginaries of the future provides an overabundance of options and can bring about novelty by shaping action in unpredictable ways.

Based on these considerations, I suggest distinguishing between different bases for decision-making of intentionally rational actors, depending on whether the situation is characterized by certainty (including risk) or uncertainty (Table 1). The concept of fictional expectations finds no application under conditions of certainty and risk, in other words, in situations where future states can in principle be known. While standard economic theory presumes that actors calculate optimal choices, behavioral economics and sociological approaches depart from seeing calculation as the

\footnotetext{
${ }^{4}$ Structuralist theories in economic sociology are closely related to economics if they consider networks and technologies to be the basis for the possibility of rational calculation (Callon 1998; Callon and Munesia 2005).

${ }^{5}$ According to Neil Fligstein (2001, p. 112), the identities of actors - that is, their interpretation of the structures of the world - are not fixed but emerge in the process of social interaction. Sabel and Zeitlin (1997, p. 15) argue that actors define "themselves strategically in the very act of constituting their context" because context is not objectively given but established through the definition of the situation carried out by the actors who are acting in these structures. The economics of conventions (Favereau and Lazega 2002) assumes the simultaneous presence of different conventions, making it necessary for actors to decide which convention holds in a specific situation, a decision that takes place in the action process and is potentially conflictual.
} 
Table 1 Rational and fictional expectations

\begin{tabular}{llll}
\hline Approach & Situation & Mode of operation & Basis for decisions \\
\hline Rational expectations approach & Certainty and risk & Calculation & Rational expectations \\
Behavioral economics & Complexity and uncertainty & Cognitive biases & Heuristics \\
Sociological institutionalism & Uncertainty & Script following & Social macrostructures \\
Sociological fictionalism & Uncertainty & Imagination & Fictional expectations \\
\hline
\end{tabular}

foundation of decision making. Behavioral economists see decisions as being shaped by the cognitive structures of the brain. Sociological (e.g., DiMaggio and Powell 1983; Beckert 1996) and some economic (e.g., Keynes [1936] 1964) assessments of uncertainty have emphasized the role of script following as a response to uncertainty. ${ }^{6}$ In this article I highlight a different response to uncertainty by bringing to the center the role of imaginaries in decision-making, which I refer to as "fictional expectations". The approach I call "sociological fictionalism".

Use of the concept of fictional expectations leads to a pragmatic understanding of action. Action is not seen teleologically as the realization of an end that itself stands outside the action process but instead as a progression in which ends and strategies are formed and revised based on contingent and changing interpretations of the situation. The connection between cognition and experience leads to a concept of situated rationality where expectations and goals are the outcome of a process unfolding in time, in which actors develop and enact projects, plans and strategies based on contingent interpretations of the situation. Fictional expectations stand close to Dewey's notion of ends-in-view, in other words, "foreseen consequences which influence present deliberation" (Dewey 1957, p. 223).

\section{Fictionality in the economy}

Several terms and concepts have been applied in the social sciences to express the contingent character of factual accounts. They include beliefs (Dewey 1957), ideas (Münnich 2011), meaning (Weber [1920] 1988), ideology (Marx [1846] 1998), imaginaries (Castoriadis 1998), fantasies (Schütz 2003), hope (Swedberg 2008), social construction (Berger and Luckmann 1966), discourse (Diaz-Bone and Krell 2009; Foucault 1970), and stories (Holmes 2009; McCloskey 1990a). The notion of fiction has been introduced before in the analysis of economic phenomena (Esposito 2007; Künzel and Hempel 2011) ${ }^{7}$ and in the philosophy of science (Vaihinger [1911] 2007). It is used here as the central concept because - as is shown below - the phenomena dealt with can be understood especially well by bringing them in contact with analytical tools

\footnotetext{
${ }^{6}$ Script following and imagination can also take place in situations with certainty and risk. Traditional action (Weber [1922] 1978) or wishful thinking would be examples. Given the assumption of intentional rationality these cases are not further explored here.

${ }^{7}$ In discussions of the financial crisis the term "fictional" is often used to describe fraudulent misrepresentations of economic facts. It is important to note that this is not how the term is used here.
} 
developed for the analysis of fictional texts. The analysis of fiction in literary theory holds insights that are also relevant for understanding contingent representations of future states. Moreover, the notion of fiction captures especially well the unknowability of the accuracy of expectations regarding future states of the world.

Although the notion of fictionality stands at the core of the article, references are made as well to some of the other concepts mentioned above, especially the notions of imaginaries, fantasies, discourse, and stories. The argument put forward relates to the work of the authors mentioned above. However, it is not possible within the bounds of this article to present a discussion on how their concepts relate to each other and to the notion of fictionality. I will also not discuss the extensive literature on imagination in the philosophy of mind (Friese 2001) and in cognitive psychology (Morris and Hampson 1983; Pylyshyn 2003; Roeckelein 2004). This must be left to later work. The main contribution of the article is to focus attention on the role of imaginaries of future states of the world as an important element in explaining present action.

\section{Fictional expectations}

To elucidate the usefulness of the notion of "fictional expectations" it is necessary first to define it. Fiction as a term derives from the Latin "fictio", which means "forming", from the verb "fingere" (to shape, to form, to make up) (Bunia 2010, p. 47; Vaihinger [1911] 2007, p. 129). According to literary theory, the main characteristic of fiction is not that it is not real-hence the mistaken opposition between fiction and reality-but that it creates a world of its own. Fiction "creates a space, in which one can in thought and imagination experience a different reality which can differ from real reality to any extent" (Bunia 2009, p. 47, own translation).

In this sense, John Searle (1975, p. 320) has characterized fiction as "non-serious". By this Searle does not mean that writing fiction is not a serious activity but that the author of fiction "isn't seriously committed" to believing that the statements he makes are indeed true propositions about the world. In other words, the worlds created through fiction are based not on an empirically observable truth but on the author's imaginings. This does not imply that there is no correspondence to reality. On the contrary, the assertions made in fictional texts achieve their credibility often because they could very well be true, because they are coherent, and because they are closely interwoven with elements that are indeed non-fictional.

My claim is that this characterization of fictional texts shows remarkable parallels to the representations of the future that economic actors develop in situations characterized by uncertainty. Because of the openness of the future such depictions must also be "nonserious" in the sense that they refer to non-observable states that may or may not materialize. At the same time, it is clear that the assessment of the situation and possible future development is not out of touch with reality but tries to take into account present empirical information and must appear coherent to create a convincing "story" of the future development of the phenomena at stake.

\section{Sources of credibility}

One question prominently debated in literary theory, but also relevant for the formation of expectations under conditions of uncertainty in economic contexts, concerns 
fiction's sources of credibility. If we know that the facts presented as true are in fact non-observable, why are fictional texts not simply disregarded as uninteresting or even as lies? Why is the reader or the holder of expectations willing to assume an attitude described by the British Romantic poet Samuel Taylor Coleridge as "the willing suspension of disbelief" (Coleridge 1817)?

Searle argues that the willingness to suspend disbelief is based on specific rules applied in the writing and reception of fictional texts but not in the writing and reception of non-fictional texts. What makes fiction possible "is a set of extralinguistic, nonsemantic conventions ... [that] enable the speaker to use words with their literal meanings without undertaking the commitments that are normally required by those meanings" (Searle 1975, p. 326). The author of fiction is "pretending" to make an assertion "or acting as if she were making an assertion" (ibid., p. 324). Pretending here does not mean that the author intends to deceive the reader, but rather that she pretends in the sense of acting "as if". The conventions are shared by readers who are willing to go along with the pretended assertions made by the author. Searle summarizes his analysis of the characteristics of fiction in the definition: "A fictional story is a pretended representation of a state of affairs" (ibid., p. 328).

To what extent can this assessment of the foundations of credibility of fictional texts be applied to the analysis of expectations under conditions of uncertainty in the economy? One important difference is undoubtedly that in economic decision-making actors scrutinize expectations not just with regard to their inherent convincingness as narratives, but with regard to their practical credibility. This refers to a distinction introduced by Alfred Schütz (2003, p. 148) between "mere fantasies", with regard to which there is no intention of putting them into practice, and "design fantasies" (Entwurfsphantasien), in respect of which there are plans to materialize them. ${ }^{8}$ However, common to both literary fiction and expectations under conditions of uncertainty is that they have a "broken relationship to reality" (Burgdorf 2011, p. 110). In the case of literary fiction this is due to a deliberate abandonment of limiting the narration to observable facts. In the case of expectations under conditions of uncertainty it is because a reality in the future cannot be known in the present.

This difference in the way the relationship to reality is broken has consequences for why actors commit themselves to the literary text or to the fictional expectation: In literary texts, conventions make readers to suspend disbelief; readers who would ask the author for proof of her assertions would clearly violate these conventions. In the case of expectations regarding an uncertain future, disbelief is suspended because the construction appears plausible enough that it could become true (Esposito 2007, p. 13). Actors scrutinize the fictional expectations with available facts and need to be convinced that the states predicted will become the "future present" (Koselleck 1988), in order to suspend disbelief. This is a discursive process in which belief remains ever fragile because the images can be contested and the actual future development remains open. Fiction in economic contexts is therefore vulnerable to contradictory experiences in the real world and at least potentially open to adaptation (Barbalet 2010: 6; Joas 1996; Putnam 2006, p. 282; Whitford 2002, p. 339). Actors do consider the fictional expectation as if it were

\footnotetext{
${ }^{8}$ Because of this, literary texts wear their fictionality on their sleeve, while non-literary fictions hide it. As Wolfgang Iser (1993, pp. 12-13) emphasizes: "In the self-disclosure of its fictionality, an important feature of the fictional text comes to the fore: it turns the whole of the world organized in the text into an 'as-if' construction".
} 
true, but only conditionally: "The rationality badge of the As If is by definition only for the present, subject to further reevaluation" (Riles 2010, p. 9). By contrast, a novel will not be rewritten because it turns out that it does not stand the test of reality.

Since in both instances actors have to come to terms with a broken relationship to reality, Searle's analysis of literary fiction entails aspects that also apply to fictional expectations, despite the differences in the sources of belief just brought up: Given fundamental uncertainty, the expectations substituting for the unachievable calculation-based anticipation of future states are not based on observable facts but on contingent assumptions about future developments that unavoidably can only "pretend" to describe a future reality and must suggest decisions based on nothing more than "as if" assumptions about the future.

Fictional expectations represent future events as if they were true, making actors capable of acting purposefully with reference to an uncertain future, even though this future is indeed unknown, unpredictable, and therefore only pretended in the fictional expectations. ${ }^{9}$ Thus the fictional expectations are "placeholders" (Riles 2010) in the decision-making process through which the unknowability of future states of the world and courses of events are overlooked for the moment. By analogy with the definition of fictional texts provided by John Searle I argue that expectations are, under conditions of uncertainty, "pretended representations of a future state of affairs". Only by being overlooked does uncertainty not lead to paralysis or randomness. Actions are based on committing to a belief in the materialization of a certain future state, and the pretention that the fictional depictions were indeed true representations of the future.

\section{Fictional expectations as stories}

The parallels between literary fictions and fictional expectations in the economy extend to the form these expectations take. One type of fictional expectation is point predictions of a future state. An example would be the prediction of an economic forecast institute, claiming, for instance, that next year the inflation rate in the United States will be $2.4 \% .{ }^{10}$ More often, however, fictional expectations take narrative form. Underlying the imagination of a certain future state is a story of how the present will be transformed through several causally linked steps into the depicted future state. Such narratives can be stories but also theories.

It is through their narrative structure that imaginings of future states become determinate (Iser 1993). ${ }^{11}$ Stories provide causal links that show how the gap

\footnotetext{
${ }^{9}$ Fictionality, moreover, allows the attribution of qualities to goods that exist only as imaginaries. This is of crucial importance in understanding the sources of consumer demand, especially in economies that are saturated in functional terms. Examples of where this aspect of imaginaries can be studied particularly well are the valuation of antiques, art, wine, and so on. This aspect of fictionality is not discussed in this article. See, however, Beckert (2011).

${ }^{10}$ With hindsight, such point predictions mostly turn out to be wrong. However, based on the theoretical considerations developed here, it would be a categorical mistake to mock such forecasts for being wrong. They are necessarily wrong because the future cannot be foreseen. The much more interesting perspective is to analyze the functions of such forecasts (and other forms of fictional expectations) for structuring action in the present.

${ }^{11}$ As Volkmann (2001, p. 15) elaborates with reference to Wolfgang Iser, the act of fictionalizing converts the diffuseness of the imaginary into a gestalt. Fictionalizing "provides the imaginary with a determinacy that it would otherwise not possess" (ibid.).
} 
between the present state of the world and the predicted future state is actually closed, thus providing plausible reasons why one should expect the depicted outcome. By bringing the narrative structure to the fore, the concept of fictional expectations connects to work on the role of stories and discourses in the social sciences. Stories have become a topic in economic sociology (Diaz-Bone and Krell 2009; Mützel 2010; White 1992), economics (Akerlof and Shiller 2009; McCloskey 1990a), organization studies (Brown et al. 2005; Czarniawska 1997), economic anthropology (Holmes 2009), and political science (Salmon 2007). ${ }^{12}$

To show how fictional expectations enter economic decision making through narratives, I introduce examples that deal with the emergence of business strategies, the formation of expectations on financial markets and the structuring of expectations through economic theory. These examples illustrate how stories are used to establish the credibility of fictional expectations or to contest them.

Business strategies Strategies are guideposts for decision-making that are produced under conditions of the unknowability of the future; in other words, conditions of uncertainty. Business strategies cannot be understood as a rational calculation of an optimal choice because the contexts of action are themselves constituted by the actors' interpretation of the situation. It is through the "articulation of stories about possible developments" (Sabel and Zeitlin 1997, p. 15) that business strategies are developed.

One example of this is provided by Sophie Mützel (2010) in a study investigating the process of strategy formation at biotechnology firms aiming to develop genetically engineered medication for breast cancer. This is a highly uncertain environment in which the success of firms' research strategies cannot be foreseen and hopes of successful product development are often disappointed. Actors' expectations take the form of narratives, which are communicated in the market field. Such narratives consist of stories of how the goal of development of a certain medical therapy can be pursued successfully. The fictional depictions are signals to competitors, informing them of the beliefs of other players with regard to promising strategies. The stories establish reciprocal perspectives on the position of each firm within the market field and "thereby have stabilizing effects within the network structure" (Mützel 2010, p. 93). The narratives have the further consequence of generating expectations in the financial community. They serve as a basis for investment decisions and can thus contribute to raising share prices by influencing investors' expectations positively, or-in case of disappointing stories regarding the outlook for a firm's strategy — to their decline.

Financial markets Financial markets are especially susceptible to the emergence of stories about future developments, as can be seen from the dotcom euphoria, the enthusiasm for the biotechnology industry in the late 1990s, or the BRIC concept a few years later. The weight of stories in financial markets can be understood as a response to the high level of uncertainty prevailing in these markets. This uncertainty has its chief cause in the self-referentiality (Orléan 2005; Shiller 2000; Soros 1998) of financial markets. In their calculative efforts, financial investors must anticipate the

\footnotetext{
${ }^{12}$ Research on narrative representations is also important in historiography (Anderson 1983). Since this research refers to the past it is not considered here. Our interest here lies in stories used to depict future events imaginatively.
} 
expectations of other investors in the market with regard to the development of market opinion (Keynes [1936] 1964). The expectations of market actors regarding the strategies of others can follow convention (Orléan 2008; Keynes [1937] 1973, p. 114), mirror peer pressure ensuing from the style of discourse (Hellwig 2008, p. 161), or reflect imaginaries (Kraemer 2010). Market-influencing stories stem from powerful investors, bank analysts, economists, or central banks and high-ranking treasury officials. These actors shape expectations through their accounts of the current economic situation and its future development. Their narratives serve as "analytical bridges to the near future" (Holmes 2009, p. 386). ${ }^{13}$

An example of this is provided by Nelson and Katzenstein (2010) who show, based on research by Douglas Holmes (2009), the role that central banks play in managing the expectations of investors by "talking to the markets" through public statements and carefully worded interviews:

Prices become anchored in the expectations of market participants who take these allegories seriously and adjust their practices and expectations. ... Together with open market operations, the economic narratives of central banks thus become the second main determinant for price developments. Put differently, uncertainty is being reduced by discursive practices that rely on strategic rhetorical action with essentially pedagogical aims (Nelson and Katzenstein 2010, p. 31f.).

Stories influence the confidence of investors that markets will develop in a certain direction and thereby influence investment decisions. This connection between stories and confidence levels has also been depicted by behavioral economists: "High confidence tends to be associated with inspirational stories, stories about new business initiatives, tales of how others are getting rich" (Akerlof and Shiller 2009, p. 55). Investment strategies are loaded, for instance, with a "growth story" that entails elements of prophecy. The stories circulating move markets by influencing demand and prices: "Stories impart meaning, which is to say worth" (McCloskey 1990b, p. 68). Stories, however, not only create worth, but can also destroy it: the "Asian crisis" in 1997 started out as a "Thai crisis". Investors took the crisis in Thailand as evidence of potential difficulties in other Asian countries (Hellwig 1998, p. 715). This opinion formed in the financial markets despite very different economic fundamentals in these countries. By withdrawing funds also from countries such as Korea, investors created the difficulties that were predicted by the story.

Fictional expectations provide justifications for investment decisions whose success is uncertain. ${ }^{14}$ The expectation, for example, that gold will rise to 2,400 dollars, put forward by commodities investor Jim Rogers in November 2011 (see Gold News

\footnotetext{
13 That expectations under conditions of uncertainty are fictions also finds confirmation in the status of the ratings of rating agencies. After ratings had proved to be wrong in the financial crisis of 2008, rating agencies stressed in their defense that their ratings are nothing but "opinions". While this was an excuse to avoid legal liability, it also confirms the argument developed here: assessments of the future in highly complex conditions are no more than "pretensions".

14 The influence of fictional depictions of future states on investments is not limited to financial markets; it is a much wider phenomenon. It shows itself, for instance, in the bequest of wealth (Beckert 2008), the buying of life insurance (Zelizer 1979, p. 595f.), the purchase of lottery tickets (Beckert and Lutter 2009), or investments in education motivated by imaginaries of intergenerational upward mobility, supported by collective narratives such as the "American dream".
} 
2011), together with justifications of why this will be the case, is a story tranquilizing intentionally rational investors with regard to their investments in the precious metal.

This is, however, also an example were fictional expectations may influence the events they predict. Rogers can foresee future prices in the commodity markets as little as anybody else, but his story may nevertheless shape expectations of other investors and thereby motivate investment decisions. This hints at the performative role (Callon 1998; MacKenzie and Millo 2003) of fictional expectations. By exercising influence on decisions, stories can become self-fulfilling prophecies, causing the success of the investment anticipated in the fictional depiction (Esposito 2007, p. 112). The shared expectations create demand for the asset, leading to higher prices that were asserted first as a pretension. In this sense, stories create "the economy itself as a communicative field and as an empirical fact" (Holmes 2009, p. 384). In hindsight, actors might interpret the outcome - for instance, that the gold price indeed climbs to 2,400 dollars - as confirmation of the accuracy of their "calculation", although the outcome is the result of the joint belief in a fictional expectation.

The performative effects of fictional expectations at the same time open up opportunities for actors to tell stories that do not represent the best of their knowledge but aim at the manipulation of expectations of others for personal gain.

Language and reasoning are not necessarily employed for the benefit of the institution for which one works; most importantly they serve the purposes of the speaker within the institution. For these purposes, it is important that one uses formulations that are effective-without necessarily being right (Hellwig 1998, p. 721).

The possibility to influence expectations of others and at the same time gain from the decisions that are based on these expectations makes the assertion appear naïve that fictional expectations are reflecting the best of knowledge being available. Holmes (2009, p. 401) for instance assumes an experimental process in which stories are open to "revision and modification as new data and new interpretative insights become available" (Holmes 2009, p. 401). A more realistic scenario seems to be that stories can prevail despite known flaws and incoherencies due to powerful particularistic interests, organizational inertia, and group pressures.

Economic theory Economic theories themselves can be seen as an influential form of storytelling in the economy (McCloskey 1985, 1990a). Economic theories provide accounts of cause-effect relations, about the effects of decisions on future development, and about the behavior of economic systems. Given the openness of the future and hence the fundamental uncertainty confronting decision makers in the economy, economic theories can also only be interpreted as fictional depictions of causal relationships and future developments. Only under the conditions specified in economic theory (full information, rationality, and so on) can expectations anchored in calculation indeed be understood as anticipations of future states. This, however, is hardly ever the case. If rational expectations are assumed in situations with fundamental uncertainty, what is claimed to be "rational expectations" are indeed camouflaged "fictional expectations". This camouflaging is important for the credibility of the theory.

Following Hans Vaihinger (Vaihinger [1911] 2007, p. XII), scientific categories and theories should be viewed as "consciously false assumptions" in the sense that 
the objects characterized do not actually possess the characteristics ascribed to them but are treated as if they held these characteristics (ibid., p. 163). These as-if assumptions of theories become relevant in decision-making because they are misread as true representations of the present situation and future development. Assuming the performative character of expectations, the expectations formulated in economic theory regarding the behavior of other actors (rationality) and of markets (equilibrium) themselves influence the development they explain and can become true in hindsight due to their influence on actors (Callon 1998; MacKenzie and Millo 2003).

An example of this is provided by Hirokazu Miyazaki (2003), who has argued in a study on arbitrage trading on the Tokyo stock exchange that this trading strategy is based on an underlying "faith" in the efficient-market hypothesis on the part of the traders. Arbitrage trading seeks to identify financial assets that are "mispriced relative to their theoretical value" (ibid., p. 258). Rather than "being true", traders act as if the efficient-market hypothesis were true. The theory is akin to utopian thought, emphasizing a gap between reality and the ideal. ${ }^{15}$ This provides a radically different perspective on rational expectations theory. Rather than prices being indeed efficient, it is the belief in their future change toward efficiency - created by the theory - that anchors trading strategies on financial markets.

\section{Fictional expectations and economic dynamics}

By not being bound to rational calculation, action has a much higher degree of freedom than is assumed by rational actor theory (Schütz 2003, p. 148f.). The images ${ }^{16}$ of the future may be untamed speculations or, at the other extreme, pretend to be a determinate representation of a future state. They are not determined by the situation and are therefore also not predictable (Tappenbeck 1999, p. 89). Due to their limitlessness, non-literary fictions are of particular importance for understanding innovative processes and hence the dynamics of the economy (Bronk 2009).

The dynamics and growth of the capitalist economy chiefly take place through innovation (Baumol 2002; Schumpeter 1912). Through innovation, new factor combinations are introduced into the market that - if successful-satisfy previously unattended needs, create new needs, or enhance efficiency in the production process. Hence it is through the investigation of innovative practices that one can understand the dynamics of the economy. In this process fictional expectations play a crucial role.

The importance of fictional expectations in innovation was already recognized by Joseph Schumpeter (1912). Schumpeter's analysis sets out from the observation that new combinations exist at the beginning only in the consciousness of the actor. While

\footnotetext{
${ }^{15}$ See also Zbaracki (2004, p. 17) who shows, based on ethnographic work in a large industrial firm, that price-setting practices make use of economic price theory. But rather than determining prices, the theory has influence because it is used to legitimate the position advocated by a group of managers in the negotiations. "Price theory may serve as a rational myth" used by actors to orient themselves in a complex situation.

${ }^{16}$ Psychological theories (Beach and Mitchell 1987) distinguish between several mental "images" through which knowledge is represented: The self-image, consisting of personal beliefs and values; the trajectoryimage, depicting a desirable future; the action-image, portraying the sequences of actions needed to achieve the desirable future; and the projected-image, which depicts the anticipated results of the action.
} 
most actors are caught up in routines, some actors "with more acute intelligence and a more active imagination envisage countless new combinations" (ibid., p. 163). As soon as the entrepreneur considers possible new combinations, he will "adapt his economic activities accordingly" (ibid., p. 165). This has direct consequences for the economy because the entrepreneur will, based on the imaginary, change the value assessment of the goods offered in the market - in other words, change product demand. This leads to changes in relative prices.

Using the terminology introduced above, the entrepreneur "pretends" the existence of the imagined new combinations in the future and structures his present behavior on the basis of these pretensions. Schumpeter insists that innovation is incompatible with the calculative behavior assumed by economic theory because innovations cannot be rationally deduced from existing knowledge. Instead, the contingent imaginaries of actors motivate and guide the inherently incalculable activity.

The emphasis on imaginaries as a crucial component of innovative processes has been confirmed in many studies empirically investigating innovation. According to van Lente and Rip (1998, p. 222) innovation processes start with the "voicing of promises" that show the way to collective projections of the future. The voicing of promises has the function not only of shaping a collective mind-set but also of protecting new ideas from disbelief so they can be cultivated. Hence, it is a utopian vision that stands at the outset, which shows a pretended future reality that comes into existence (or does not) as a result of the activities anchored in the fictional expectation at the outset. Sturken and Thomas (2004, p. 7) argue that technological vision is "not simply a means to characterize new technology, rather it serves both to define new technologies and to construct them". According to David Nye (2004), technological predictions are narratives about our desires for the future, rather than accurate reflections of technological capabilities.

Expressed in more abstract terms, imagination makes possible "conceptual jumps which allow us to generate new hypotheses and see things differently" (Bronk 2009, p. 203). They allow actors to move beyond inherited thought-patterns and categories by bringing them into an as-if world in which given reality is surpassed and a different one considered (Bronk 2009, p. 201; Tappenbeck 1999, p. 53). The creative re-thinking of the parameters of a decision situation based on imaginaries makes it possible to reorganize links in a "new narrative texture" (Patalano 2003, p. 4). In this sense, the fictional can be "subversive of established order" (Bronk 2009, p. 201). The indeterminacy of fictional expectations is also an indispensable basis for what David Stark (2009) has called the "sense of dissonance": Different fictional expectations can be operational at the same time. Entrepreneurship exploits the opportunities opened up by this indeterminacy in the interpretation of the situation.

On theoretical grounds the connection between imagination and innovativeness has been maintained in particular by the theories of economists working in the Keynesian and Austrian traditions and in the Carnegie School. The Keynesian economist George Shackle (1979), for instance, sees the uncertain basis of expectations as allowing for the freedom to create hitherto unexplored visions of the future. Choice is choice "amongst imagined experiences" (Shackle 1964, p. 12). According to Buchanan and Vanberg ([1984] 2008), choices of entrepreneurs are not between possibilities that are already "out there", but "the reality of the future must be made by choices yet to be made, and this reality has no existence independent of these choices" (ibid., p. 386). Hence, any knowledge of the future "can be a matter of speculation, but not of foreknowledge" 
(ibid., p. 385). In a market economy, this lack of foreknowledge is at the same time a source of innovativeness. Markets institutionalize the "creative-inventive-imaginative element in choice" (ibid., p. 389). From an organizational perspective, James March sees fictionality as a non-rational decision device contributing to actors' opportunities to engage in innovations: "Soothsayers create sheltered worlds of ignorance, ideology and faith. Within the shell that they provide, craziness is protected long enough to elaborate its challenge to orthodoxy (March 1995, p. 437).

\section{Fictional expectations as a motivating force for action}

To become economically relevant, fictional expectations must influence action. Only by being a source of action is the fiction-ability of humans (Iser 1993) not simply an illusion but of practical significance. In rational actor theory, agents are assumed to have a natural propensity to maximize their utility. In sociological approaches emphasizing institutions or cultural frames, actors are motivated by an internalized desire to conform to social norms (Parsons 1951), fear of sanctions, or the urge to maintain a state they define as "normal" (Garfinkel 1967).

The motivational source of "imagined experiences" (Shackle 1964, p. 12) is different from these accounts. It is based on the inspiring force that images of the future can have for action in the present. Following the work of Albert Hirschman (1986) and George Shackle (1979) I consider this force to be largely emotional. ${ }^{17}$ Through "imagination [an actor] can perceive an attainable state of thought and realize it as an attained satisfaction" (Shackle 1979, p. 47). The imagined outcomes of choices evoke emotions of an "enjoyment by anticipation" (Shackle 1979, p. 45) that are instant rewards for the personal commitment to a particular action. ${ }^{18}$

Although the focus here is on action in the economy, it is worth recognizing that immediate rewards stemming from the commitment to a fictional expectation seem to be a motivating force also outside the realm of the economy. Albert Hirschman has investigated this idea in relation to political commitments and has shown the parallel with religious beliefs. Quoting Blaise Pascal, Hirschman argues that the "hope which Christians have of possessing an infinite good is mingled with real enjoyment, [...] they hope for holiness, for freedom from injustice, and they have something of this" (Pascal [1672] 1958, p. 145). Hirschman (1986, p. 150) then applies this idea to the understanding of political activities: the members of a group fighting for a revolutionary goal experience a sensation of the utopian state while they are engaged in the struggle, although they indeed live in the present under the most oppressive conditions. To experience this sensation, however, the actor must have committed himself to the struggle for the goal. ${ }^{19}$

\footnotetext{
${ }^{17}$ For investigations in economic sociology on the role of emotions see Bandelj (2009), Barbalet (1998), Beckert (2006), Berezin (2005), DiMaggio (2002), and Pixley (2004).

18 This is also supported by findings from neuroscience that show that the brain regions activated when imagining pleasurable events are the same as the ones activated when actually experiencing these events (Costa et al. 2010; Speer et al. 2009).

${ }^{19}$ Again, there seems to be a parallel to fictional literature that can also produce "quasi emotions" (Walton 1990 , p. 37) in the reader who empathizes with the fate of the characters.
} 
The emotional basis of the motivating force of fictional expectations can be exemplified by a study by Geny Piotti (2009) investigating the decision-making processes of German firms outsourcing parts of their production to China. What motivated firms to go to China? Piotti shows from the interviews conducted with managers involved in these decisions that the choice was not so much rooted in economic calculation as motivated by a general euphoria with regard to investment in China created by the media and industry organizations, such as chambers of commerce. The depictions of the opportunities presented through narratives by firms already operating in China triggered overly optimistic assessments, motivating decisions that often led to losses. Some managers interviewed by Piotti compared the decision to outsource to China explicitly "to the Gold Rush in America" (Piotti 2009, p. 23). Narratives of the great opportunities opening up in China, strong normative pressures in the field, and sentiments of euphoria were major ingredients in the decision to relocate.

Pleasurable sensations experienced by actors from anticipation help to explain their willingness to commit themselves to (uncertain) endeavors and to overcome environmental pressures towards conformity. "The attachment to a fantasy converts the ambiguities of history into confirmations of belief and a willingness to persist in a course of action" (March 1995, p. 437). The entrepreneur contemplating the relocation of his firm to China already "enjoys" the profits yet to be made. This is similar to the lottery player seeing himself already as the winner of the jackpot, experiencing some of the sensations he would experience when actually winning it (Beckert and Lutter 2009). In psychological terms, "high-risk behavior, like play and exploration in organizations that insist on rationality, may heighten the intensity of feelings, and may motivate a commitment to, for example, projects that are at the same time imagined with a substantial amount of disbelief" (Augier and Kreiner 2000, p. 678).

\section{The role of calculation and social macrostructures}

So far, the concept of fictional expectations has been developed in juxtaposition to the concepts of rational expectations and social macrostructures as the two devices identified in economics and sociology as forming the basis of decision-making. To introduce the concept of fictional expectations, however, is not to imply negation of the role of calculation and social macrostructures in decision-making processes. How do fictional expectations relate to them?

\section{Calculation and fictional expectations}

Approaches stressing the role of imaginaries in economic decision-making emphasize that actors attempt to make decisions that increase their utility and therefore must combine imagination with reason (Bronk 2009; Buchanan and Vanberg [1984] 2008; Shackle 1961). Hence it would be a grave misunderstanding to see the introduction of the concept of fictional expectations as promoting a theory of naïveté. Creative moments solidify

into an action-guiding vision of a possible future ... only if we judge them rationally as likely to be feasible and pertinent in the light of experience. Imagined futures and creative solutions often go way beyond what can be 
rationally deduced from today's facts and hypotheses; but these potential futures and creative solutions must be stress-tested (so far as possible) by a rational and ethical audit, if they are not to lead us unnecessarily astray (Bronk 2009 , p. 206).

George Shackle underlined that "imagination must be constrained to be congruous with what the decision-maker knows of things in general and of human nature" (Shackle 1961, p. 11). The oscillation between unbound imaginaries and calculation can be seen, for instance, in relationships involving trust: actors attempt to obtain information on the cooperation partner and interpret carefully the signals that are available regarding the person's trustworthiness (Bacharach and Gambetta 2001; Beckert 2005). Ultimately, however, the freedom of the trust-taker to defect cannot be eliminated and the decision to trust resembles a "leap" not justified by calculation, but based on faith and judgment, anchored in the as-if portrayal of the behavior of the trust-taker that he will honor the trust (Karpik 2010; Möllering 2006).

Investors also engage in meticulous calculative practices to find out about the likely prospects of an investment. However, the impossibility of including genuine novelty in such a calculation and the complexity of the decision situation keep the representation of future development always a fictional expectation. Rather than leading to the recognition of the optimal choice in an objective sense, calculative assessments of outcomes should - under conditions of fundamental uncertainty - be considered fictions themselves (Dobbin 2001); because it appears rational, calculation as a form of storytelling provides legitimated justifications for decisions despite the incalculability of outcomes. Hence, calculations in situations characterized by fundamental uncertainty have an entirely different role than the one assumed by the actors themselves: they are not instruments that make it possible to anticipate the future, but tranquilizers against the paralyzing effects of having to act in unpredictable environments. Calculation helps in overlooking the profound uncertainty entailed in decisions by increasing commitment to what remain fictional expectations.

\section{Macrostructures and fictional expectations}

Social macrostructures - that is, institutions, networks, and cultural frameworks - are connected in several ways to the emergence and stability of fictional expectations:

Institutional structures and networks can reduce uncertainty in the action situation and thereby support specific fictions. The imagination that the trust conferred in a business partner will not be exploited is facilitated by social networks (Granovetter 2005) and an effective legal system (Coleman 1990). Likewise, entrepreneurial ideas depend "to a significant degree on the institutional framework in which innovators operate; and the ability of new ideas to take root likewise depends on the institutional environment" (Bronk 2009, p. 299). The channeling of contingencies through rules and social networks does not imply a deterministic force on the part of these rules with regard to the imaginaries: the creativity of actors exercised in the imagining of future states of the world remains and actors must also always reckon with opportunistic behavior. However, a situation structured by rules and networks is less open than one without such social macrostructures. 
Cultural frames shape the direction of fictional expectations. This is an important aspect for the sociological understanding of the conditions under which imaginaries become "successful" in the sense that they become shared by larger social groups. Studies on innovation show that the proliferation of technological visions - that is, their influence on investors - often depends on their connections to normative ideas of a "better society". Examples of this include investments in renewable energies or in the housing market that are anchored in a cultural discourse of utopian visions for society (Sturken and Thomas 2004). Another example is culturally rooted expectations of economic accomplishment. Innovation as a form of deviant behavior is also anchored in the normative structure of modern capitalist societies, which value innerworldly transcendence through industriousness and success-seeking by risk taking (Merton 1957), and thereby encourage deviant imaginaries and the associated actions. The cultural frame is a powerful ingredient in imaginaries of a life in which these cultural expectations are fulfilled. The imaginaries take on concrete forms as depictions of a life in wealth through "creative destruction". Hence, including fictional expectations in a theory of economic decision-making does not deny the relevance of social structures. Seen from the perspective of the actor these macrostructures are typifications that guide imaginaries in culturally and institutionally rooted ways. To understand how exactly fictional expectations are connected to cultural frames and the more general question of what makes imaginaries "successful" are among the most pertinent research questions for the further development of the line of reasoning introduced here.

\section{Conclusion}

This article sets out from the proposition that decision-making in the economy cannot be understood as the result of rational calculation of the factors relevant for the outcome or as the force of social macrostructures. Fundamental uncertainty due to "unknown and unknowable" future events (Dequech 2003) prevents rational calculations from accurately anticipating the future. This implies that the expectations that intentionally rational actors hold are not of the kind assumed by rational expectations theory. The proposition developed in the article states instead that expectations are fictional in the sense that they are based on pretensions of future states of the world.

Understanding decision processes based on the concept of fictionality points to a non-teleological theory of action that brings the creativity of actors and the contingency of the future into the foreground (Joas 1996). The goal is not to develop a more accurate theory of prediction but rather a theory of the unpredictability of the world and of how intentionality unfolds despite this unpredictability of outcomes. The "fiction-ability" (Iser 1993) of humans allows for the imaginative representation of future states of the world in the mind and the imagining of decisions of other actors. The fictional representations of future states shape expectations and provide justifications for decisions, reducing the ever possible disorientation of decision-makers due to the openness of the future. The concept of fictionality suggests an alternative not only to calculation-based models in economics, but also to the focus on social macrostructures prevailing in sociological approaches to the economy. It brings to the fore the role of images of the future for the understanding of the present and thereby 
departs from theories in the social sciences that see the present as being determined through the past.

The fiction-ability of humans is a source of innovation and novelty. Humans can imagine a world different from the existing one, and "inhabit" this world through mental representations. Imaginaries can transcend the known and thereby motivate decisions that create newness. This ability to imagine things that never were contributes to actual future states by motivating actions. To include fictionality in a theory of decision-making provides a tool for understanding the dynamics of the economy from a micro perspective.

Fictional expectations, however, are not teleological in the sense that actors fix a future state in their mind and all steps to be taken derive from this representation of a goal. Instead, imaginaries and courses of action emerge in a reciprocal process in which goals and means inform each other, based on experiences of the situation and their interpretation (Dewey [1938] 1998; Holmes 2009), as well as the power structures in the field (Hellwig 1999, 2008). Calculation enters this dialogical process continuously when actors attempt to find "proof" of the soundness of the imaginaries constituting their decisions. Social macrostructures enter the process by shaping the imaginaries themselves through cognitive frames and through institutions supporting actors in realizing specific imaginaries. In this sense, imaginaries are socially anchored and not purely individual.

If action is not determined by rational calculation or social structures, but also based on contingent imaginaries of future states, it follows also that the imaginaries become contested. Although fictional representations do not anticipate actual future states they influence decisions in the present. These decisions have distributional consequences in the market, consequences for macroeconomic development, and consequences for the institutionalization of regulatory rules. Financial markets are especially obvious targets for the strategic spread of fictional expectations - if other investors can be convinced of the future state these fictions depict, they are a source of profit opportunities. Hence a theory of fictional expectations is necessarily also a theory of politics in the sense that it considers the influencing of expectations as one of the crucial activities of actors in the economy.

This "management of expectations" (Beckert 2013) through the influencing of expectations is not relevant just to understanding the intentionality of action but also for macroeconomic development. In the aggregate, expectations shape the development of economic processes. "The great over-all processes of economic life-inflation, deflation, depression, recovery, and economic development are governed largely by the process of reorganization of economic images through the transmission of messages" (Boulding 1956, p. 90). Making fictionality an essential element of a theory of intentionally rational decision-making provides a vantage point for the understanding of the microfoundations of the dynamics of capitalism and the sources of economic growth.

In this article most aspects of a theory of fictional expectations could only be touched upon. But behind the considerations presented stands the perspective for a theoretical and empirical research program. As shown, this program builds upon work in the social sciences from very different sources that it bundles under the concept of fictional expectations. Empirical studies need to investigate how in concrete settings expectations regarding future developments and understandings of 
causal relationships emerge, stabilize, and change. They must investigate the strategic use of expectations as well as the motivating force standing behind them and the anchoring of expectations in cultural frames and institutional structures.

Acknowledgments I would like to thank the two anonymous Theory and Society reviewers for their very helpful comments. For comments on earlier versions of this article I would like to thank David Dequech, Christoph Deutschmann, Arne Dreßler, Martin Hellwig, Sebastian Kohl, Sophie Mützel, and Werner Rammert.

\section{References}

Akerlof, G. A., \& Shiller, R. (2009). Animal spirits. How human psychology drives the economy, and why it matters for global capitalism. Princeton: Princeton University Press.

Allais, M. (1953). Le comportement de l'homme rationnel devant le risque: critique des postulats et axiomes de l'école Américaine. Econometrica, 21, 503-546.

Anderson, B. (1983). Imagined communities: reflections on the origin and spread of nationalism. London: Verso.

Augier, M., \& Kreiner, K. (2000). Rationality, imagination and intelligence: some boundaries in human decision-making. Industrial and Corporate Change, 9, 659-681.

Bacharach, M., \& Gambetta, D. (2001). Trust in society. In K. S. Cook (Ed.), Trust in society (pp. 148184). New York: Russel Sage.

Bandelj, N. (2009). Emotions in economic action and interaction. Theory and Society, 38, 347-366.

Barbalet, J. (1998). Emotion, social theory, and social structure: a macrosociological approach. Cambridge: Cambridge University Press.

Barbalet, J. (2010). Action theoretic foundations of economic sociology. Kölner Zeitschrift für Soziologie und Sozialpsychologie. Sonderband, 49, 143-157.

Beach, L. R., \& Mitchell, T. R. (1987). Image theory: Principles goals, and plans in decision making. In Acta Psychologica 66.

Beckert, J. (1996). What is sociological about economic sociology? Uncertainty and the embeddedness of economic action. Theory and Society, 25, 803-840.

Beckert, J. (2002). Beyond the market. The social foundations of economic efficiency. Princeton: Princeton University Press.

Beckert, J. (2003). Economic sociology and embeddedness. How shall we conceptualize economic action? Journal of Economic Issues, 37, 769-787.

Beckert, J. (2005). Trust and the performative construction of markets. Köln: Max-Planck-Institut für Gesellschaftsforschung. MPIfG Discussion Paper 05/8.

Beckert, J. (2006). Was tun? Die emotionale Konstruktion von Zuversicht bei Entscheidungen unter Ungewissheit. In A. Scherzberg (Ed.), Kluges Entscheiden. Disziplinäre Grundlagen und interdisziplinäre Verknüpfungen (pp. 123-141). Tübingen: Mohr Siebeck.

Beckert, J. (2008). Inherited wealth. Princeton: Princeton University Press.

Beckert, J. (2011). The transcending power of goods. In J. Beckert \& P. Aspers (Eds.), The worth of goods (pp. 106-128). Oxford: Oxford University Press.

Beckert, J. (2013). Capitalism as a system of fictional expectations. Toward a sociological microfoundation of political economy. Politics and Society (forthcoming).

Beckert, J., \& Lutter, M. (2009). The inequality of fair play. Lottery gambling and social stratification in Germany. European Sociological Review, 25, 475-488.

Berezin, M. (2005). Emotions and the economy. In N. J. Smelser \& R. Swedberg (Eds.), Handbook of economic sociology (pp. 9-127). New York: Russell Sage.

Berger, P. L., \& Luckmann, T. (1966). The social construction of reality: A treatise in the sociology of knowledge. Garden City: Anchor Books.

Boulding, K. E. (1956). The image. Ann Arbor: The University of Michigan Press.

Bronk, R. (2009). The romantic economist. Imagination in economics. Cambridge: Cambridge University Press. Brown, J. S., et al. (2005). Storytelling in organizations. Burlington: Elsevier Butterworth-Heinemann.

Buchanan, J., \& Vanberg, V. ([1984] 2008). The market as a creative process. In D. Hausmann (Ed.), The philosophy of economics (pp. 379-398). Cambridge: Cambridge University Press. 
Bunia, R. (2010). Was ist Fiktion? Kunstforum, 202, 46-53.

Burgdorf, A. (2011). Virtualität und Fiktionalität-Überlegungen zur Finanzwelt als "Vorstellungsraum". In C. Künzel \& D. Hempel (Eds.), Finanzen und Fiktionen (pp. 107-118). Frankfurt/M: Campus Verlag.

Callon, M. (Ed.). (1998). The laws of the markets. Oxford: Blackwell Publishers.

Callon, M., \& Munesia, F. (2005). Economic markets as calculative collective devices. Organization Studies, 26, 229-1250.

Camerer, C. F., Loewenstein, G., \& Rabin, M. (Eds.). (2003). Advances in behavioral economics. Princeton: Princeton University Press.

Camic, C. (1986). The matter of habit. The American Journal of Sociology, 91, 1039-1087.

Castoriadis, C. (1998). The imaginary institution of society. Cambridge: MIT Press.

Coleman, J. S. (1990). Foundations of social theory. Cambridge: Harvard University Press.

Coleridge, S. T. (1817). Biographia Literaria. <http://www.gutenberg.org/cache/epub/6081/pg6081.html>.

Costa, V. D., et al. (2010). Emotional imagery: assessing pleasure and arousal in the brain's reward circuitry. Human Brain Mapping, 31, 1446-1457.

Czarniawska, B. (1997). Narrating the organisation. Chicago: University of Chicago Press.

Dequech, D. (2003). Conventional and unconventional behavior under uncertainty. Journal of Post Keynesian Economics, 26, 145-168.

Dequech, D. (2006). The new institutional economics and the behaviour under uncertainty. Journal of Economic Behavior and Organization, 59, 109-131.

Dewey, J. (1957). Human nature and conduct. An introduction to social psychology. New York: The Modern Library.

Dewey, J. ([1938] 1998). The pattern of inquiry the essential John Dewey. Bloomington: Indiana University Press, 169-179.

Diaz-Bone, R., \& Krell, G. (Eds.). (2009). Diskurs und Ökonomie. Wiesbaden: VS Verlag für Sozialwissenschaften.

DiMaggio, P. (2002). Endogenizing "animal spirits": toward a sociology of collective response to uncertainty and risk. In M. F. Guillén et al. (Eds.), The new economic sociology. Developments in an emerging field (pp. 79-100). New York: Russell Sage.

DiMaggio, P., \& Powell, W. (1983). The iron cage revisited: institutional isomorphism and collective rationality in organizational fields. American Sociological Review, 48, 147-160.

Dobbin, F. (2001). How institutional economics is killing microeconomics. Economic Sociology Listserve.

Dobbin, F. (2004). The sociological view of the economy. In F. Dobbin (Ed.), The new economic sociology. A reader (pp. 1-46). Princeton: Princeton University Press.

Elster, J. (2009). Excessive ambitions. Capitalism and Society, 4, 1-30.

Esposito, E. (2007). Die Fiktion der wahrscheinlichen Realität. Frankfurt a.M: Suhrkamp.

Favereau, O., \& Lazega, E. (2002). Conventions and structures in economic organization. Cheltenham: Edward Elgar.

Fligstein, N. (2001). Social skill and the theory of fields. Sociological Theory, 19, 105-125.

Foucault, M. (1970). The order of things: An archeology of the human sciences. New York: Vintage Books.

Friese, H. (2001). Imagination: History of the concept international encyclopedia of the social and behavioral sciences (pp. 7197-7201). Oxford: Elsevier Publishers.

Garfinkel, H. (1967). Studies in ethnomethodology. Cambridge: Polity Press.

Gold News (2011). <http://goldnews.bullionvault.com/gold_price_111020117>.

Granovetter, M. (1985). Economic action and social structure: the problem of embeddedness. American Journal of Sociology, 91, 481-510.

Granovetter, M. (2005). The impact of social structure on economic outcomes. Journal of Economic Perspectives, 19, 33-50.

Güth, W., \& Kliemt, H. (2010). (Un)Eingeschränkt rational entscheiden in Geschäft und Moral. In Berlin Brandenburgische Akademie der Wissenschaften (Ed.), Preis der Berlin-Brandenburgischen Akademie der Wissenschaften gestiftet von der Commerzbank Stiftung. Preisverleihung am 19. Oktober 2009: Weyma Lübbe. Berlin: BBAW.

Hellwig, M. (1998). Discussion on international contagion: what is it and what can be done against it? Swiss Journal of Economics and Statistics, 134, 715-739.

Hellwig, M. (1999). Zur "volkswirtschaftlichen Verantwortung" der Banken. In F. Jaeger (Ed.), Die volkswirtschaftliche Verantwortung der Banken. Rüegger: Chur.

Hellwig, M. (2008). Systemic risk in the financial sector: An analysis of the subprime-mortgage financial crisis (Vol. 157). Bonn: Max Planck Institute for Research on Collective Goods. Preprints of the Max Planck Institute for Research on Collective Goods Bonn 2008/43. 
Hirschman, A. (1986). Rival views of market society. New York: Viking.

Holmes, D. R. (2009). Economy of words. Cultural Anthropology, 24, 381-419.

Iser, W. (1993). The fictive and the imaginary: Charting literary anthropology. Baltimore: Johns Hopkins University Press.

Joas, H. (1996). The creativity of action. Chicago: University of Chicago Press.

Karpik, L. (2010). Valuing the unique. The economics of singularities. Princeton: Princeton University Press.

Keynes, J. M. ([1936] 1964). The general theory of employment, interest, and money. London: MacMillan.

Keynes, J. M. ([1937] 1973). The general theory of employment. In: The collected writings of J.M. Keynes. London: Macmillan, 109-123.

Knight, F. H. ([1921] 1985). Risk, uncertainty, and profit. Chicago: University of Chicago Press.

Koselleck, R. (1988). Vergangene Zukunft: Zur Semantik geschichtlicher Zeiten. Frankfurt/M: Suhrkamp Verlag.

Kraemer, K. (2010). Propheten der Finanzmärkte. Zur Rolle charismatischer Ideen im Börsengeschehen. Berliner Journal für Soziologie, 20, 179-201.

Künzel, C., \& Hempel, D. (2011). Finanzen und Fiktionen. Frankfurt/M: Campus Verlag.

Lucas, R. (1972). Expectations and the neutrality of money. Journal of Economic Theory, 4, 103-124.

MacKenzie, D., \& Millo, Y. (2003). Constructing a market, performing theory: the historical sociology of a financial derivatives exchange. The American Journal of Sociology, 109, 107-145.

Mahony, J. (2000). Path dependence in historical sociology. Theory and Society, 29, 507-548.

March, J. G. (1995). The future, disposable organizations and the rigidities of imagination. Organization, 2 , $427-440$

Marx, K. ([1846] 1998). The German ideology. Oxford: Blackwell.

McCloskey, D. (1985). The rhetoric of economics. Madison: The University of Wisconsin Press.

McCloskey, D. (1990a). If you're so smart. The narrative of economic expertise. Chicago: The University of Chicago Press.

McCloskey, D. (1990b). Storytelling in economics. In D. Lavoie (Ed.), Economics and hermeneutics. New York: Routledge.

Merton, R. (1957). Social theory and social structure. Glencoe: The Free Press.

Mische, A. (2009). Projects and possibilities: Researching futures in action. Sociological Forum, 24, 694-704.

Miyazaki, H. (2003). The temporalities of the market. American Anthropologist, 105, 255-265.

Möllering, G. (2006). Trust: reason, routine, reflexivity. Oxford: Elsevier.

Morris, P. E., \& Hampson, P. (1983). Imagery and consciousness. London: Academic.

Münnich, S. (2011). Interest-seeking as sense-making: ideas and business interests in the new deal. European Journal of Sociology, 52, 277-311.

Muth, J. F. (1961). Rational expectations and the theory of price movements. Econometrica, 29, 315-335.

Mützel, S. (2010). Koordinierung von Märkten durch narrativen Wettbewerb. Kölner Zeitschrift für Soziologie und Sozialpsychologie. Sonderband, 49, 87-106.

Nelson, S., \& Katzenstein, P. J. (2010). Uncertainty and risk and the crisis of 2008. Ithaca: Cornell University. Nye, D. E. (2004). Technological prediction. In M. Sturken, D. Thomas, \& S. J. Ball-Rokeach (Eds.), Technological visions (pp. 159-185). Philadelphia: Temple University Press.

Orléan, A. (2005) The self-referential hypothesis in finance. Paris.

Orléan, A. (2008). Knowledge in finance: objective value versus convention. Paris.

Orléan, A. (2011). L'Empire de la Valeur. Paris: Editions du Seuil.

Parsons, T. (1951). The social system. London: Routledge.

Pascal, B. ([1672] 1958). Pensées. New York, NY: E. P. Dutton \& Co., Inc.

Patalano, R. (2003). Beyond rationality: Images as guide-lines to choice. Torino: University of Torino. Vol. 05/2003.

Piotti, G. (2009). German companies engaging in China. Decision-making processes at home and management practices in Chinese subsidiaries. Köln: Max-Planck-Institut für Gesellschaftsforschung. MPIfG Working Paper 09/14.

Pixley, J. (2004). Emotions in finance: Distrust and uncertainty in global markets. Cambridge: Cambridge University Press.

Putnam, R. A. (2006). Democracy and value inquiry. In J. R. Shook \& J. Margolis (Eds.), A companion to pragmatism (pp. 278-289). Malden: Blackwell Publishing.

Pylyshyn, Z. W. (2003). Seeing and visualizing: It's not what you think. Cambridge: MIT Press.

Riles, A. (2010). Collateral expertise. Current Anthropology, 51, 1-25.

Roeckelein, J. E. (2004). Imagery in psychology: A reference guide. Westport: Praeger Publishers.

Sabel, C. F., \& Zeitlin, J. (1997). Stories, strategies, structures: Rethinking historical alternatives to mass production. In C. F. Sabel \& J. Zeitlin (Eds.), World of possibilities. Flexibility and mass production in western industrialization (pp. 1-33). Cambridge: Cambridge University Press. 
Salmon, C. (2007). Storytelling. La machine à fabriquer des histoires et à formater les esprits. Paris: La Découverte.

Schumpeter, J. (1912). Theorie der wirtschaftlichen Entwicklung. Berlin: Duncker \& Humblot.

Schütz, A. (2003). Das Problem der Personalität in der Sozialwelt. Bruchstücke. In R. Grathoff, H.-G. Soeffner, \& I. Srubar (Eds.), Alfred Schütz Werkausgabe: Theorie der Lebenswelt 1. Die pragmatische Schichtung der Lebenswelt (pp. 91-177). Konstanz: UVK Verlagsgesellschaft mbH.

Searle, J. (1975). The logical status of fictional discourse. New Literary History, 6, 319-332.

Shackle, G. L. S. (1961). Decision, order and time in human affairs. Cambridge: Cambridge University Press.

Shackle, G. L. S. (1964). General thought-schemes and the economist. Woolwich: Woolwich Polycentric Press. Woolwich Economic Paper 2.

Shackle, G. L. S. (1979). Imagination and the nature of choice. Edinburgh: Edinburgh University Press.

Shiller, R. J. (2000). Irrational exuberance. Princeton: Princeton University Press.

Simon, H. (1957). Models of man. New York: Wiley.

Soros, G. (1998). The crisis of global capitalism: Open society endangered. New York: PublicAffairs.

Speer, N., et al. (2009). Reading stories activates neural representations of visual and motor experiences. Psychological Science, 20, 989-999.

Stark, D. (2009). The sense of dissonance: Accounts of worth in economic life. Princeton: Princeton University Press.

Storper, M., \& Salais, R. (1997). Worlds of production. Cambridge: Harvard University Press.

Sturken, M., \& Thomas, D. (2004). Introduction. Technological visions and the rhetoric of the new. In M. Sturken, D. Thomas, \& S. J. Ball-Rokeach (Eds.), Technological visions (pp. 3-18). Philadelphia: Temple University Press.

Swedberg, R. (2008). The sociological study of hope and the economy: Introductory remarks. Ithaca: Cornell University.

Tappenbeck, I. (1999). Phantasie und Gesellschaft. Zur soziologischen Relevanz der Einbildungskraft. Würzburg: Königshausen und Neumann.

Vaihinger, H. ([1911] 2007) Die Philosophie des Als Ob. Saarbrücken: VDM Verlag.

van Lente, H., \& Rip, A. (1998). Expectations in technological developments: An example of prospective structures to be filled in by agency. In C. Disco \& B. van der Meulen (Eds.), Getting new technologies together. Studies in making sociotechnical order (pp. 203-229). Berlin: de Gruyter.

Volkmann, C. (2001). Organization theory and literary theory: Strange encounters. Exeter: School of Business \& Economics. Vol. 03/01.

Walton, K. (1990). Mimesis as make believe: On the foundations of the representational arts. Cambridge: Harvard University Press.

Weber, M. ([1920] 1988). Die Wirtschaftsethik der Weltreligionen. In M. Weber (Ed.), Gesammelte Aufsätze zur Religionssoziologie I. Tübingen: J.C.B. Mohr/Siebeck UTB, 237-573.

Weber, M. ([1922] 1978). Economy and society. Berkeley: University of California Press.

White, H. (1992). Identity and control. A structural theory of social action. Princeton: Princeton University Press.

Whitford, J. (2002). Pragmatism and the untenable dualism of means and ends: why rational choice theory does not deserve paradigmatic privilege. Theory and Society, 31, 325-363.

Zbaracki, M. J. (2004). Pricing structure and structuring price. Philadelphia: University of Pennsylvania. Zelizer, V. (1979). Morals and markets: The development of life insurance in the United States. New York: Columbia University Press.

Jens Beckert is Director of the Max Planck Institute for the Study of Societies in Cologne and Professor of Sociology at the University of Cologne. He has held visiting positions at Princeton University, Harvard University, Cornell University, the European University Institute, and Sciences Po and the Institut d'études avancées in Paris. The main focus of his research is economic sociology with a particular emphasis on markets, organization studies, the sociology of inheritance and social theory. He is the author of two monographs on the sociology of markets (Princeton University Press 2002) and on the sociology of inheritance (PUP 2008). His articles have been published in journals such as Theory and Society, Sociological Theory, Organization Studies, and the European Journal of Sociology. 